\title{
Morphological and molecular identification of ascomycetous coprophilous fungi occurring on feces of some bird species
}

\author{
Torbati $\mathbf{M}^{\mathbf{1}}$, Arzanlou $\mathbf{M}^{\mathbf{2}^{*}}$ and Bakhshi $\mathbf{M}^{3}$ \\ ${ }^{I}$ PhD Student of Plant Pathology, Plant Protection Department, Faculty of Agriculture, University of Tabriz, PO Box: \\ 5166614766, Iran \\ ${ }^{2}$ Associate Professor of Plant Pathology and Mycology, Plant Protection Department, Faculty of Agriculture, \\ University of Tabriz, PO Box: 5166614766, Iran. \\ ${ }^{3}$ Assistant professor, Department of Botany, Iranian Research Institute of Plant Protection, P.O. Box 1454, Tehran 19395, \\ Iran.
}

Torbati M, Arzanlou M, Bakhshi M 2016 - Morphological and molecular identification of ascomycetous coprophilous fungi occurring on feces of some bird species. Current Research in Environmental \& Applied Mycology6(3), 210-217, Doi 10.5943/cream/6/3/9

\begin{abstract}
Coprophilous fungi are a highly diverse assemblage encompassing all major groups of fungi and have important role in decomposition and recycling of animal feces, especially feces of herbivores. The present study was aimed to characterize ascomycetous fungi associated with the feces of some birds including sparrow and crow. Fresh fecal samples were collected in paper bags and taken into the laboratory. About $0.05 \mathrm{~g}$ of each sample was transferred on to acidified Potato Dextrose Agar medium (PDA) (containing $2 \mathrm{ml}$ of $20 \%$ lactic acid/liter) and cultures were kept in $25^{\circ} \mathrm{C}$ in incubator. Pure cultures were established using single spore or hyphal tip techniques. Then fungal isolates were identified based on morphological characteristics and sequence data from ITS-rDNA region. In this study we report Alternaria alternata, Paraconiothyrium fungicola, Chaetomium murorum, Fusarium solani, Cladosporium herbarum, Sarocladium strictum and Epicoccum nigrum as fungal mycobiota associated with the feces of birds.
\end{abstract}

Key words - herbivores - Sparrow - Crow - ITS-rDNA

\section{Introduction}

Coprophilous (Dung loving) fungi encompass a heterogeneous assemblage from all major groups of fungi. They play important role in decomposition and recycling of animal feces, particularly feces of herbivores and also biodegradation of organic materials especially in heavily manured soils and mushroom beds (Angel \& Wicklow 1974, Wicklow 1981). These fungi are an important component of the ecosystem and the study of these small individual community or mycobiota has been advocated for the experimental study of ecosystems (Rattan \& El-Buni 1979, Richardson 2001). Coprophilous fungi have adapted for life on feces of animals (Ingold 1953, Webster 1970, Lodha 1974) and passage of the fungal spores through the digestive system of an animal is often necessary to facilitate spore germination (Richardson 2008). Most of coprophilous fungi can be cultivated on media but some groups of coprophilous fungi e.g. from Zygomycota need growth factors for their growth and sporulation. Therefore, it is necessary to use various feces of animals mainly herbivores as a substrate. These fungi are an ecologically highly adapted group, capable of assimilating nutrients that are not 
used when plant material passes through the digestive tract of an animal, therefore aiding decomposition processes and helping to recycle these nutrients in the environment. Moreover, they are an excellent example to demonstrate the biodiversity of fungi.

In spite of their importance and suitability for cultural study, coprophilous fungi have received little attention in Iran. The present study was aimed to characterize ascomycetous fungi associated with the feces of some birds including sparrow and crow.

\section{Material and Methods}

\section{Isolates and morphology}

Feces of sparrow and crow were collected in paper envelops (during summer 2013) from different regions of Tabriz metropolis and taken to the laboratory. The samples were gently air dried, then about $0.05 \mathrm{~g}$ of each sample was transferred on to acidified Potato Dextrose Agar medium (PDA) (containing $2 \mathrm{ml}$ of $20 \%$ lactic acid/liter) and cultures were kept in $25^{\circ} \mathrm{C}$ in incubator. Pure cultures were established using single spore or hyphal tip techniques. Axenic cultures were deposited in the Culture Collection of Tabriz University (CCTU) and a complete list of the isolates used in this study is presented in Table 1. Then fungal isolates were identified based on morphological characteristic on different culture media such as PDA, MEA (Malt Extract Agar), CLA (Carnation Leaf Agar) and PCA (Potato Carrot Agar) as well as sequence data of ITS-rDNA region.

\section{DNA extraction, amplification and sequencing}

For DNA extraction, fungal isolates were grown on PDA for eight days in the dark and fresh mycelia were harvested and subjected to DNA extraction using the protocol of Moller et al. (1992). DNA samples were subsequently diluted 100 times in preparation for further DNA amplification reactions. Part of the nuclear rRNA operon spanning the 3' end of 18S rRNA gene, the first internal transcribed spacer, the 5.8S rRNA gene, the second ITS region and the 5' end of the 28S rRNA gene (ITS) were amplified and sequenced using the primer pairs V9G (de Hoog \& Gerrits van den Ende 1998) + ITS4 (White et al. 1990). PCR reaction mixtures and conditions were performed in a total volume of $12.5 \mu \mathrm{L}$ as described by Bakhshi et al. (2015). Following PCR amplification, amplicons were visualized on $1.2 \%$ agarose gels stained with GelRed ${ }^{\mathrm{TM}}$ (Biotium, Hayward, CA, USA) and viewed under ultra-violet light and sizes of amplicons were determined against a HyperLadder ${ }^{\mathrm{TM}}$ I molecular marker (Bioline, London, UK)

The resulting fragments were sequenced in both directions using the PCR primers and ABI Prism BigDye ${ }^{\circledR}$ Terminator Cycle sequencing reaction kit v. 3.1 (Applied Biosystems ${ }^{\mathrm{TM}}$, Foster City, CA, USA) following the manufacturer's instructions. DNA sequencing amplicons were purified through Sephadex G-50 Superfine columns (Sigma Aldrich, St. Louis, MO) in 96-well MultiScreen HV plates (Millipore, Billerica, MA). Purified sequence reactions were analysed on an ABI Prism 3730XL Automated DNA analyzer (Life Technologies Europe BV, Applied Biosystems ${ }^{\mathrm{TM}}$, Bleiswijk, The Netherlands) as outlined by the manufacturer.

\section{Sequence analysis}

The DNA sequences generated, were edited using MEGA v. 6 (Tamura et al. 2013) and a consensus sequence was generated manually for each set of trace files from the forward and reverse sequences. Sequences were subjected to Megablast search analysis at NCBI's GenBank nucleotide database for sequence similarity.

\section{Results}

Forty-eight ascomycetous fungal isolates were recovered from feces (Tables 1, 2). The fungal isolates belonged to the species of the genera Alternaria, Epicoccum, Paraconiothyrium, Chaetomium, Sarocladium, Cladosporium and Fusarium. The isolation frequency of each fungal group is provided in figure 1. In this study we report Alternaria alternata, Paraconiothyrium fungicola, Chaetomium murorum, Fusarium solani, Cladosporium herbarum, Sarocladium strictum and Epicoccum nigrum as 
Table 1 Strains included in this study and their identity in GenBank

\begin{tabular}{|c|c|c|c|c|}
\hline isolate & location & Hosts & morphological and molecular identification & Identity (\%) \\
\hline CCTU & Tabriz & Crow & Alternaria alternata & 100 \\
\hline CCTU & Tabriz & Sparrow & Fusarium solani & 99 \\
\hline CCTU & Tabriz & Sparrow & Epicoccum nigrum & 100 \\
\hline CCTU & Tabriz & Crow & Chaetomium murorum & 99 \\
\hline CCTU & Tabriz & Sparrow & Paraconiothyrium fungicola & 98 \\
\hline CCTU & Tabriz & Sparrow & Paraconiothyrium fungicola & 98 \\
\hline CCTU & Tabriz & Sparrow & Sarocladium strictum & 99 \\
\hline CCTU & Tabriz & Crow & Alternaria alternata & 100 \\
\hline CCTU & Tabriz & Sparrow & Paraconiothyrium fungicola & 98 \\
\hline CCTU & Tabriz & Sparrow & Epicoccum nigrum & 98 \\
\hline CCTU & Tabriz & Crow & Alternaria alternata & 100 \\
\hline CCTU & Tabriz & Crow & Chaetomium murorum & 99 \\
\hline CCTU & Tabriz & Sparrow & Epicoccum nigrum & 98 \\
\hline CCTU & Tabriz & Crow & Alternaria alternata & 100 \\
\hline CCTU & Tabriz & Crow & Chaetomium murorum & 99 \\
\hline CCTU & Tabriz & Crow & Chaetomium murorum & 99 \\
\hline CCTU & Tabriz & Crow & Alternaria alternata & 100 \\
\hline CCTU & Tabriz & Sparrow & Epicoccum nigrum & 98 \\
\hline CCTU & Tabriz & Sparrow & Epicoccum nigrum & 98 \\
\hline CCTU & Tabriz & Sparrow & Paraconiothyrium fungicola & 98 \\
\hline CCTU & Tabriz & Crow & Alternaria alternata & 100 \\
\hline CCTU & Tabriz & Sparrow & Paraconiothyrium fungicola & 98 \\
\hline CCTU & Tabriz & Sparrow & Epicoccum nigrum & 98 \\
\hline CCTU & Tabriz & Sparrow & Paraconiothyrium fungicola & 98 \\
\hline CCTU & Tabriz & Sparrow & Sarocladium strictum & 99 \\
\hline CCTU & Tabriz & Crow & Chaetomium murorum & 99 \\
\hline CCTU & Tabriz & Crow & Chaetomium murorum & 99 \\
\hline CCTU & Tabriz & Sparrow & Epicoccum nigrum & 98 \\
\hline CCTU & Tabriz & Sparrow & Paraconiothyrium fungicola & 98 \\
\hline CCTU & Tabriz & Crow & Cladosporium herbarum & 98 \\
\hline CCTU & Tabriz & Sparrow & Sarocladium strictum & 99 \\
\hline CCTU & Tabriz & Sparrow & Paraconiothyrium fungicola & 98 \\
\hline CCTU & Tabriz & Sparrow & Epicoccum nigrum & 98 \\
\hline CCTU & Tabriz & Sparrow & Epicoccum nigrum & 98 \\
\hline CCTU & Tabriz & Crow & Alternaria alternata & 100 \\
\hline CCTU & Tabriz & Crow & Alternaria alternata & 100 \\
\hline CCTU & Tabriz & Crow & Alternaria alternata & 100 \\
\hline CCTU & Tabriz & Crow & Alternaria alternata & 100 \\
\hline CCTU & Tabriz & Sparrow & Epicoccum nigrum & 98 \\
\hline CCTU & Tabriz & Sparrow & Paraconiothyrium fungicola & 98 \\
\hline CCTU & Tabriz & Sparrow & Paraconiothyrium fungicola & 98 \\
\hline CCTU & Tabriz & Crow & Chaetomium murorum & 99 \\
\hline CCTU & Tabriz & Sparrow & Epicoccum nigrum & 98 \\
\hline CCTU & Tabriz & Sparrow & Paraconiothyrium fungicola & 98 \\
\hline CCTU & Tabriz & Sparrow & Fusarium solani & 99 \\
\hline CCTU & Tabriz & Sparrow & Epicoccum nigrum & 98 \\
\hline CCTU & Tabriz & Crow & Chaetomium murorum & 99 \\
\hline CCTU & Tabriz & Sparrow & Fusarium solani & 99 \\
\hline
\end{tabular}


fungal mycobiota associated with the feces of sparrow and crow in Tabriz metropolis, that two species i.e., Chaetomium murorum and Paraconiothyrium fungicola for the first time are reported for Iran as coprophilous fungi.

Chaetomium murorum Corda 1837

Fig. 2

Colony on PCA containing one piece of filter paper reaching $35 \mathrm{~mm}$ in diam after 10 days, flat, circular, entire, colorless to grey, forming ascomata in relatively concentrically zonate pattern in 3 sectors mostly at the center of the colony; the colony and agar reverse, except where ascomata are formed, remain uncolored. Ascomata globose to broadly ellipsoidal or ovoidal, lacking an elongated neck and a dark collar. Peridium variously textured. Terminal hairs of several types. Asci clavate. Ascospores biseriate to conglobate, variously shaped, with an apical germ pore. Immature ascospores non-dextrinoid, brown or grey at maturity ellipsoid-fusiform or ovoidal, rarely limoniform, then mixed with ovoidal ascospores, with attenuated, sometimes apiculate ends, greyish brown. Peridium and terminal hairs are different, Peridium from textura angularis to epidermoidea, sometimes cephalothecoidea around the hair bases (Fig. 2). Terminal hairs flexuous at the apex and often open circinate. Ascospores usually equilateral, 13-16 × 7.5-9 $\mu \mathrm{m}(13-17 \times 7-9)$ based on Stchigel et al. (2004).

\section{Paraconiothyrium fungicola Verkley \& Wicklow 2004}

Fig. 3

Colonies on MEA reaching of 35-38 mm diam after $14 \mathrm{~d}$; restricted and already elevated in the centre. Colony surface covered by a dense mat of woolly, pure white to honey or pale yellow. Pycnidia developing around the centre of the colony after $14 \mathrm{~d}$. Colonies on OA reaching $65 \mathrm{~mm}$ diam after $14 \mathrm{~d}$, spreading, with glabrous, colourless margin; colony surface with a diffuse coverage of pure white, low, finely felty or floccose aerial mycelium. Pycnidia developing on the surface of the colony from $14 \mathrm{~d}$ (Fig. 3). Conidiomata superficial or immersed in the medium, eustromatic, dark brown to black, $0.3-$ 1(-1.5) $\mathrm{mm}$ diam. Conidiogenous cells discrete, phialidic, occasionally indeterminate, proliferating percurrently 1-3 times (only on PDA dominating) formed from the inner cells all over the conidiomatal wall, hyaline, subglobose, or broadly to narrowly ampulliform, sometimes with a relatively wide elongated neck, with an indistinct periclinal thickening, collarette absent, 5-7(-9) $\times 3-5 \mu \mathrm{m}$; conidia one-celled, ovoid, ellipsoid to short-cylindrical, broadly rounded at both ends or slightly tapering towards one end, some constricted in the middle, or two-celled, constricted around the euseptum, with up to $0.4 \mu \mathrm{m}$ thick, smooth walls which are hyaline at secession, but soon become reddish-brown, contents vinaceous to olivaceous, minutely granular with a few small guttules near the poles, conidial mass dark brown to black; conidia on OA 1-celled (4.2-) 4.4-6.2(-7) $\times(2.7-) 3-3.4(-3.6) \mu \mathrm{m}$, 2-celled $7 \times 3 \mu \mathrm{m}$; on MEA 1-celled (4-)5-6(-7) $\times(2.7-) 3-3.7(-4.8)$, 2-celled 6-8 $\times$ 4.5-5.2 $\mu \mathrm{m}$; on PDA, 1celled (4-)4.5-6(-7) × (3-)3.2-4(-4.3) $\mu \mathrm{m}$, two-celled not observed base on Damm et al. (2007).

\section{Discussion}

Some coprophilous fungi provided in this paper highlight the paucity of knowledge on the diversity of coprophilous fungi in Iran. The animal feces comprise partly of undigested food materials rich in carbon, nitrogen and decomposition of ecosystem energetic that are suitable substrates for growth of various microorganism (Angel \& Wicklow 1974, Halffter \& Matthews 1971). The mycobiota on a particular feces is more or less constant depending on the nature of food intake of the animal and the environment where the feces is excreted. Previous studies on coprophilous mycobiota indicate that this group is an important component of ecosystems, responsible for recycling the biomass in animal feces, and the study of these microcosms has been advocated for the experimental study of ecosystems (Wicklow 1981). Wicklow \& Moore (1974) and Yocom \& Wicklow (1980) reported the of detailed and quantitative experimental studies on the effect of environmental conditions on the coprophilous succession and community differentiation, using pellets from laboratory rabbits fed on a uniform diet of alfalfa from a single source. Wicklow (1992) also noted that there are few experimental data on substrate preference and no information on the effects of chemical composition of dung on fruiting and colonization. Lundqvist (1972), as an introduction to his detailed taxonomic studies of the 
Table 2 Morphological characters of coprophilous fungi species studied

\begin{tabular}{|c|c|c|c|}
\hline Fungal isolates & Colony & Conidiophore & Conidia \\
\hline $\begin{array}{lr}\text { Sarocladium } & \text { strictum } \\
\text { (W. Gams) } & \text { Summerb } \\
2011 & \end{array}$ & $\begin{array}{l}\text { creamy pink and mostly } \\
\text { slimy at the center, } \\
\text { occasionally fluffy with } \\
\text { conical tufts of hyphae }\end{array}$ & $\begin{array}{l}\text { erected with conidial } \\
\text { heads arising from raised } \\
\text { columns of hyphae, } \\
\text { simple, erect, hyaline, } \\
\text { septate at base }\end{array}$ & $\begin{array}{l}\text { in slimy heads, hyaline, } \\
\text { unicellular, cylindrical } \\
\text { and germinated with a } \\
\text { single germ tube }\end{array}$ \\
\hline $\begin{array}{l}\text { Alternaria alternata } \\
\text { (Fr.) Keissl } 1912\end{array}$ & $\begin{array}{l}\text { profuse mycelial growth } \\
\text { observed on medium, } \\
\text { initially hyaline turned to } \\
\text { grey-brown with age, } \\
\text { septate and irregularly } \\
\text { branched }\end{array}$ & $\begin{array}{l}\text { raised singly or in } \\
\text { clusters, pale olivaceous } \\
\text { to olivaceous-brown, } \\
\text { straight or curved, } \\
\text { geniculate, slightly } \\
\text { swollen at apex with } \\
\text { terminal scars indicating } \\
\text { the point of attachment of } \\
\text { conidia }\end{array}$ & $\begin{array}{l}\text { in chains, light olivaceous } \\
\text { to dark brown, obclavate } \\
\text { to mostly ellipsoidal, } \\
\text { muriform with tapered } \\
\text { apex with } 1 \text { to } 3 \\
\text { longitudinal and } 2-10 \\
\text { transverse septa }\end{array}$ \\
\hline $\begin{array}{l}\text { Cladosporium herbarum } \\
\text { (Pers.) Link } 1816\end{array}$ & olivaceous-green, velvety & $\begin{array}{l}\text { with terminal and } \\
\text { intercalary swelling and } \\
\text { geniculate elangation }\end{array}$ & $\begin{array}{l}\text { ellipsoidal to cylindrical } \\
\text { with rounded ends, } \\
\text { distinctly verruculose, } 2 \\
\text { or more celled }\end{array}$ \\
\hline $\begin{array}{l}\text { Epicoccum nigrum Link } \\
1816\end{array}$ & felty, orange to red & $\begin{array}{l}\text { Short, clustered and } \\
\text { producing of dark spots } \\
\text { on medium, this spots are } \\
\text { spordochium }\end{array}$ & $\begin{array}{l}\text { conidia globose to } \\
\text { pyriform with a funnel } \\
\text { shaped base }\end{array}$ \\
\hline $\begin{array}{l}\text { Fusarium solani (Mart.) } \\
\text { Sacc. } 1881\end{array}$ & $\begin{array}{l}\text { white to creamy with low } \\
\text { aerial mycelium, color of } \\
\text { colony from the behind of } \\
\text { petri dish is yellow to } \\
\text { brown }\end{array}$ & mono and polyphialidic & $\begin{array}{l}\text { macroconidia relatively } \\
\text { thick, straight to slightly } \\
\text { curved with } 4 \text { to } 8 \text { cells, } \\
\text { base cell with heels and } \\
\text { apical cell are round, with } \\
\text { sporodochium, } \\
\text { microconidia ovoid, } \\
\text { sausage shape, one or two } \\
\text { cells, with clamydospores }\end{array}$ \\
\hline
\end{tabular}
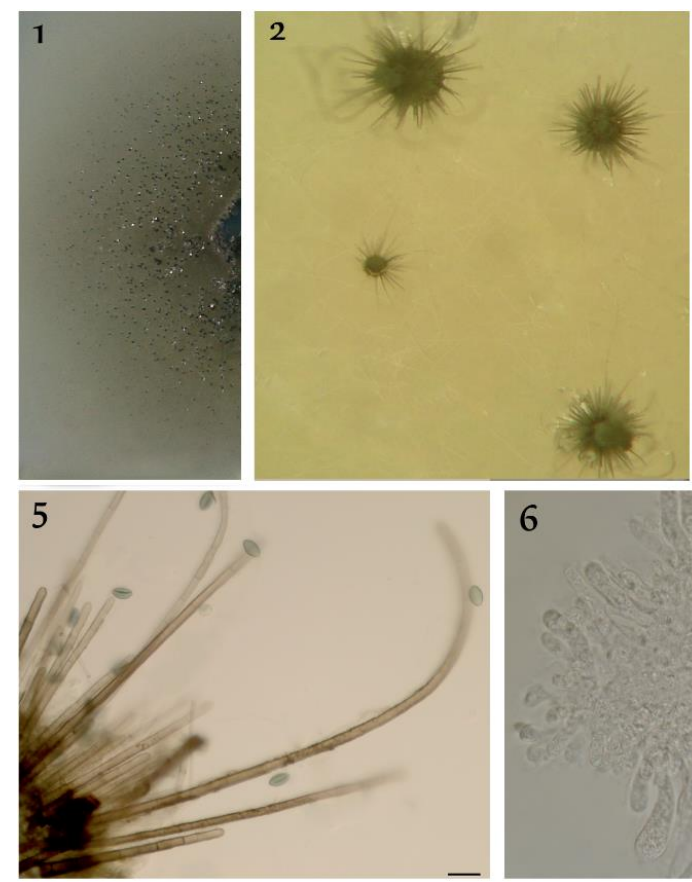
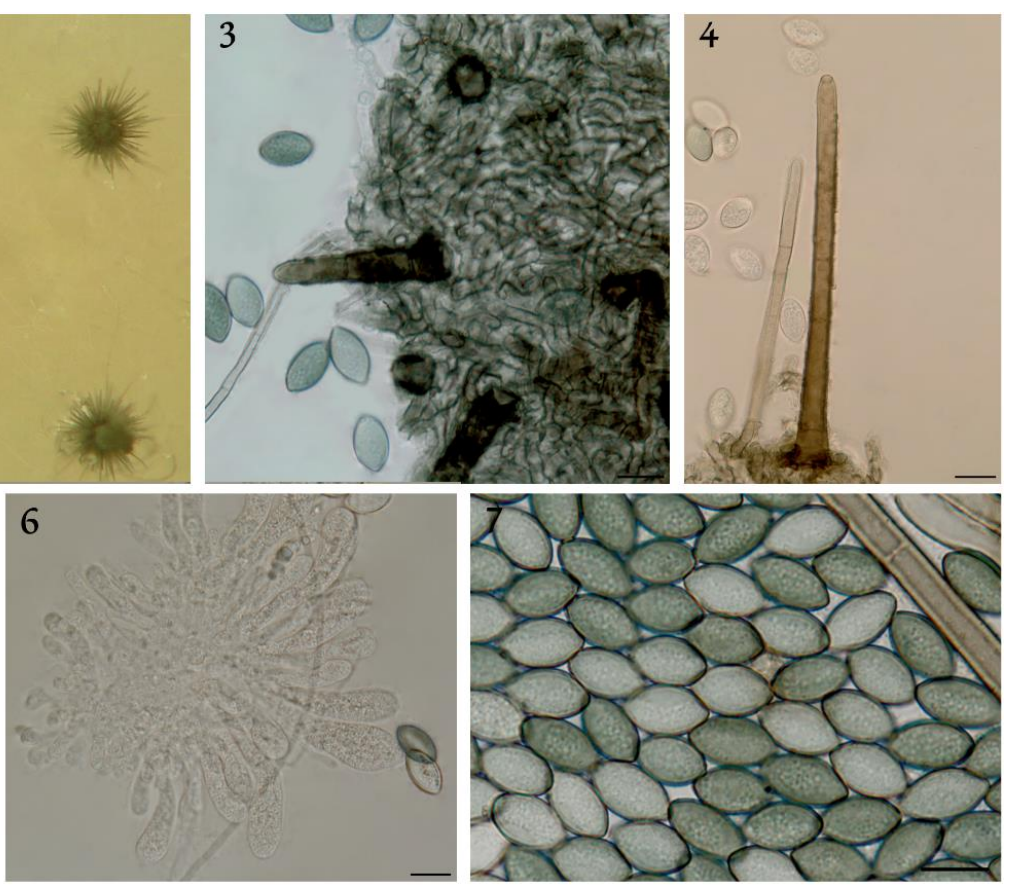

Fig. 2 - Chaetomium murorum. 1 colony on PCA containing one piece of filter paper. 2 Ascomata. 3 Cephalothecoid peridium. 4, 5 Ascomatal hairs. 6 Asci and ascospores. 7 Mature ascospores. - Bars= 3,4 and $5,6=10 \mu \mathrm{m}, 7=20 \mu \mathrm{m}$. 

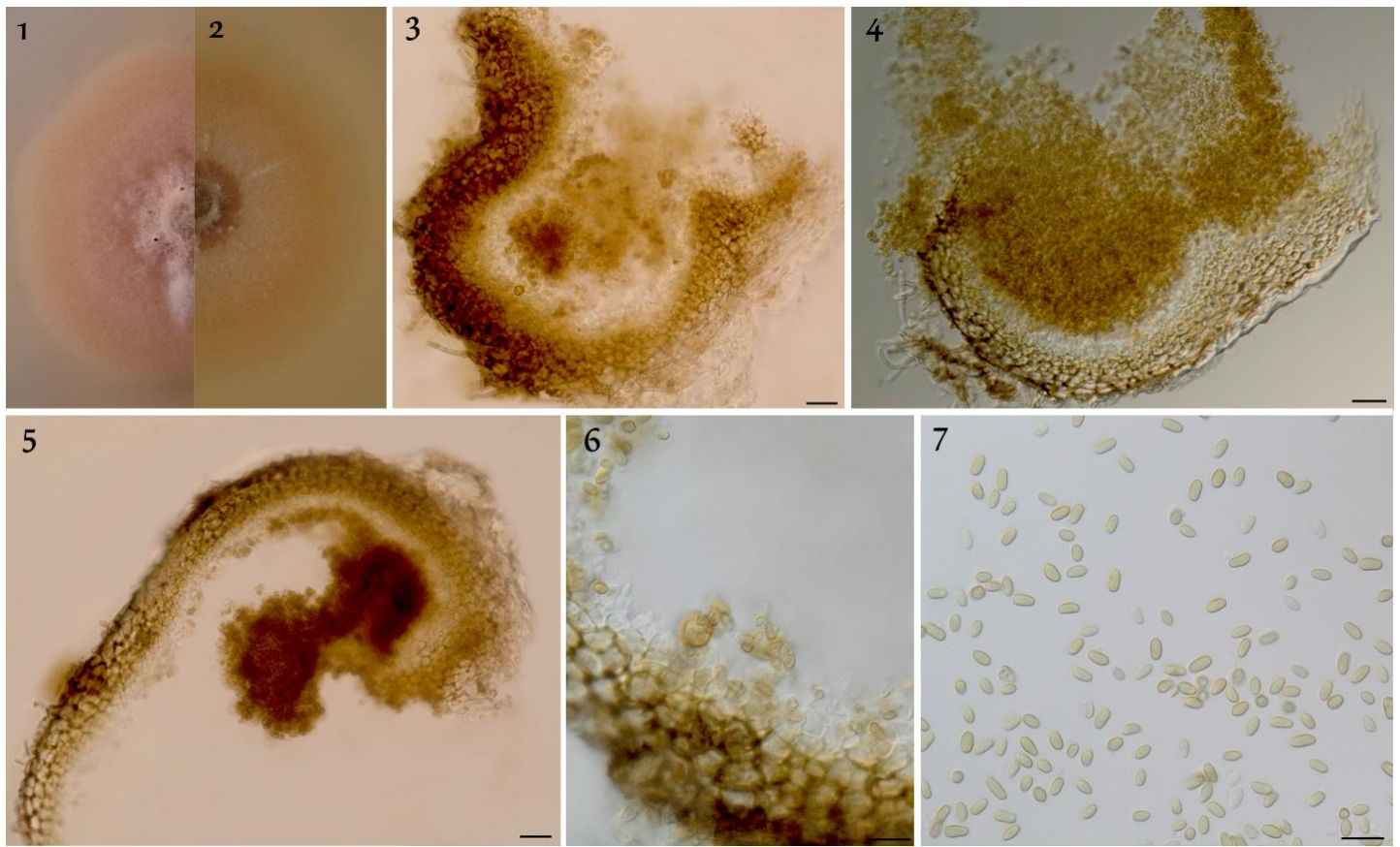

Fig. 3 - Paraconiothyrium fungicola. 1, 2 colonies on MEA and OA respectively. 3, 4, 5 conidiomata. 6 conidiophore. 7 conidia. - Bars $=3,4,5=20 \mu \mathrm{m} ; 6,7=10 \mu \mathrm{m}$.

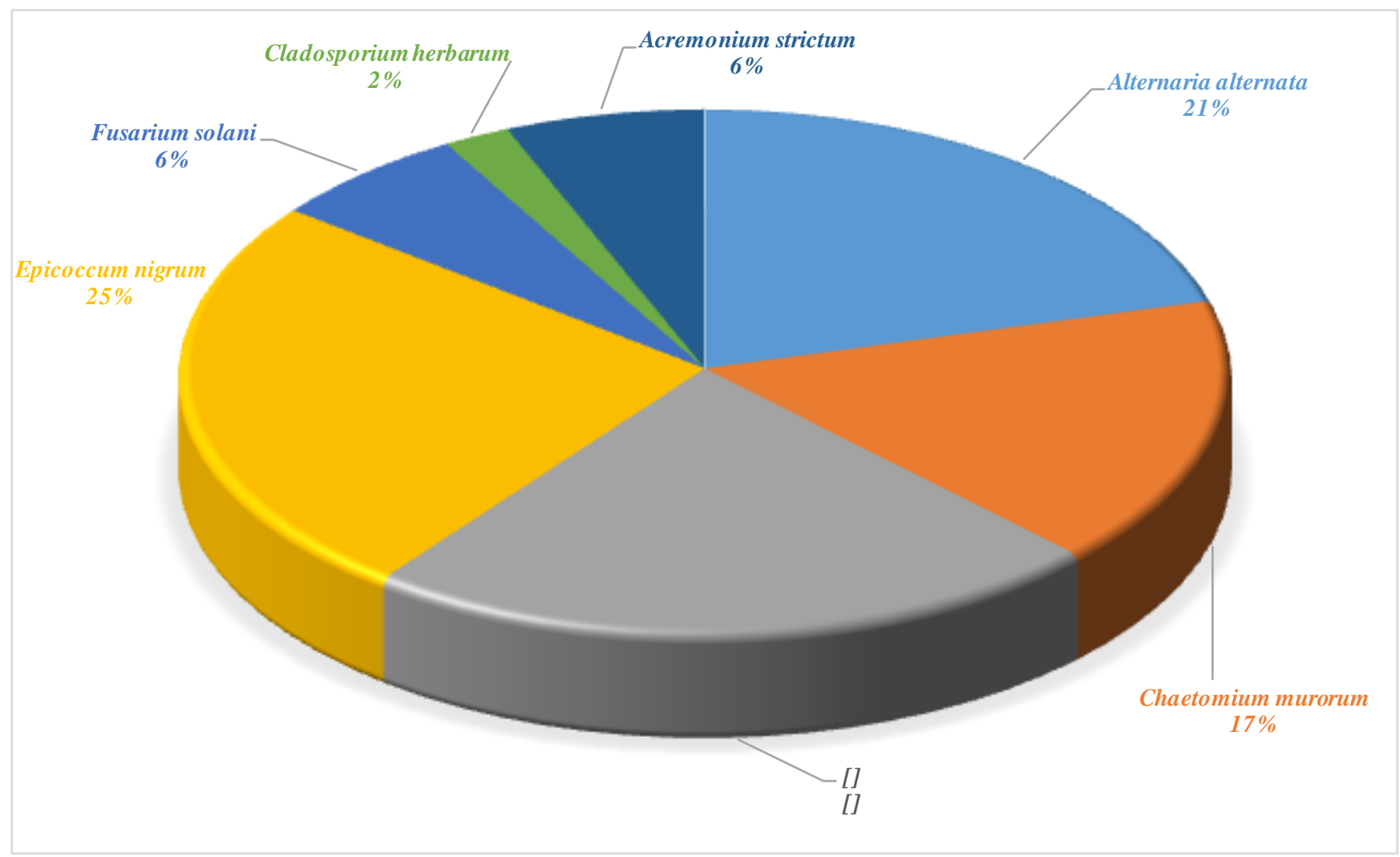

Fig. 1 - Frequency of coprophilous fungi isolates on feces

Sordariaceae, provided information on the preferred hosts and distribution of many species of coprophilous fungi, based on a very large number (approaching 1000) of samples, mainly from Scandinavia and also from Europe and other parts of the world. He noted that although Cain (1934), Hesseltine et al. (1953), and Pidacks et al. (1953) reported that the growth factor from feces is required for the growth and sporulation of some genera. The present study aimed to characterize coprophilous fungi from the north-eastern province of Iran based on a combination of DNA phylogeny and 
morphological characteristics, about seven species of ascomycetous fungi have been found on fecal samples. The highest number i.e. 29 isolates were found associated with sparrow feces followed by 19 isolates on crow feces. In this paper to the best of our knowledge we have described Chaetomium murorum and Paraconiothyrium fungicola for the first time in Iran based on morphological similarity and molecular data from ITS-rDNA region (Ershad 2009). The morphological and cultural features of our isolates were in full agreement with the description provided by Stchigel et al. (2004), Damm et al. (2007) and others.

The coprophilous fungi belonging to other groups, their impacts on other biodiversity and distribution and occurrence of coprophilous fungi in Iran remain to be studied.

\section{Acknowledgement} research.

We thank the Research Deputy of the University of Tabriz, for financial support of this

\section{References}

Angel K, Wicklow DT. 1974 - Decomposition of rabbit feces: an indication of the significance of the coprophilous microflora in energy flow schemes. Journal of Ecology 62, 429-437.

Bakhshi M, Arzanlou M, Babai-ahari, A, Groenewald JZ, Braun U, Crous PW. 2015 - Application of the consolidated species concept to Cercospora spp. from Iran. Persoonia 34, 65-86.

Cain RF. 1934 - Studies of Coprophilous Sphaeriales in Ontario. University of Toronto Studies, Biological Series, No. 38.

Damm U, Crous PW, Fourie PH. 2007 - Botryosphaeriaceae as potential pathogens of Prunus species in South Africa, with descriptions of Diplodia africana and Lasiodiplodia plurivora spp. nov. Mycologia: 99, 664-680.

de Hoog GS, Gerrits van den Ende AHG. 1998 - Molecular diagnostics of clinical strains of filamentous Basidiomycetes. Mycoses 41 (5-6), 183-189.

Ershad D. 2009 - Fungi of Iran.3rd ed. Iranian Research Institute of Plant Protection, Tehran, Iran.

Halffter G, Matthews E. 1971 - The natural history of dung beetles: A supplement on associated biota. Revista Latinoamer. Microbiology 13, 147-163.

Hesseltine CW, Whitehill AR, Pidacks C, Tenhagen M, Bohonos M, Hutchings BL, Williams JH. 1953 - Coprogen, a new growth factor present in dung required by Pilobolus species. Mycologia 45, 7-19.

Ingold CT. 1953 - Dispersal in Fungi. Clarendon Press, Oxford.

Lodha, BC. 1974 - Decomposition of digested litter. In Biology of plant litter decomposition. Eds. Dickinson, C. H. and G. H. Pugh, Academic Press, New York 213-241.

Lundqvist N. 1972 - Nordic Sordariaceae s. lat. Symbolae Botanicae Upsalienses 20(1) : 1-314.

Moller EM, Bahnweg G, Geiger HH. 1992 - A simple and efficient protocol for isolation of high molecular weight DNA from filamentous fungi, fruit bodies, and infected plant tissues. Nucleic Acids Results 20 (22), 6115-6116.

Pidacks C, Whitehill AR, Pruess LM, Hesseltine CW, Bohonos N, Williams JH. 1953 - Coprogen, the isolation of a new growth factor required by Pilobolus species. Journal of the American Chemical Society 75, 6064-6065.

Rattan SS, El-Buni AM. 1979 - Some New Records of Coprophilous Fungi from Libya. Sydowia 32, 260-276.

Richardson MJ. 2001 - Diversity and occurrence of coprophilous fungi. Mycological Research 105(4), 387-402.

Richardson MJ. 2008 - Records of Coprophilous Fungi from the Lesser Antilles and Puerto Rico. Caribbean Journal of Science, 44 (2), 206-214. 
Stchigel AM, Guarro J, Jato V, Aira MJ. 2004 - Two new species of Chaetomidium (Sordariales). Studies in Mycology 50, 215-220.

Tamura K, Stecher G, Peterson D, Filipski A, Kumar S. 2013 - MEGA6: Molecular Evolutionary Genetics Analysis Version 6.0 Molecular Biology and Evolution 30, 2725-729.

Webster J. 1970 - Coprophilous fungi: Presidential address. Transactions of the British Mycological Society 54, 161-180.

White TJ, Bruns T, Taylor J. 1990 - Amplification and direct sequencing of fungal ribosomal RNA genes for phylogenetics. p. 315-322. In: "A guide to molecular methods and applications" (M.A. Innis, D.H. Gelfand, J.J. Sninsky, J.W. White, eds.). Academic Press, New York, USA, $482 \mathrm{pp}$.

Wicklow DT, Moore V. 1974 - Effect of incubation temperature on the coprophilous fungal succession. Transactions of the British Mycological Society 62, 411-415.

Wicklow DT. 1981 - The coprophilous fungal community: A mycological system for examining ecological ideas. In The Fungal Community: its organization and role in the ecosystem (D. T. Wicklow \& G. C. Carroll, eds): 47-76. Marcel Dekker, New York.

Wicklow DT. 1992 - The coprophilous fungal community: An experimental system. In The Fungal Community: its organization and role in the ecosystem (G. C. Carroll \& D. T. Wicklow, eds): 715-728. 2nd edn Marcel Dekker, New York.

Yocom DH, Wicklow DT. 1980 - Community differentiation along a dune succession: an experimental approach with coprophilous fungi. Ecology 61, 868-880. 